\title{
Crude oil prices pass-through to retail petroleum product prices in Nigeria: evidence from hidden cointegration approach
}

\author{
D. O. Olayungbo ${ }^{1} \cdot$ T. A. Ojeyinka ${ }^{1}$
}

Received: 2 September 2020 / Accepted: 26 May 2021 / Published online: 5 June 2021

(c) The Author(s), under exclusive licence to Springer Science+Business Media, LLC, part of Springer Nature 2021

\begin{abstract}
This study produces the first-ever analysis in Nigeria on the asymmetric response of petroleum product prices to international crude oil prices by employing the hidden cointegration approach on quarterly data spanning from 1973Q1 to 2020Q2. After the preliminary tests of data description, unit root analysis and cointegration test, we find that positive and negative components of both the crude oil and petroleum prices move together in the long run. The result suggests evidence of long-run asymmetry in Nigeria. The empirical findings from both the long-run and short-run results show that petroleum prices in Nigeria respond asymmetrically to changes in crude oil prices. Specifically, the outcomes from the study reveal that positive changes (increase) in crude oil prices produce a larger and stronger effect on petroleum prices than the effect of negative changes (decrease) in crude oil prices indicating evidence of an asymmetric relationship between the two prices in Nigeria. Thus, the findings confirm the existence of the rocket and feather hypothesis in the retail energy market in Nigeria. Overall, the study finds convincing evidence to support the hypothesis of "rocket and feather" in the pass-through effect of crude oil prices on petroleum prices in Nigeria. The study advocates for more government intervention in the energy market to reduce the welfare loss associated with an increase in crude oil prices on the citizens.
\end{abstract}

Keywords Crude oil price $\cdot$ Retail petroleum product price $\cdot$ Rocket and feather hypothesis $\cdot$ Hidden cointegration $\cdot$ Nigeria

JEL Classification Q41 · C22

\section{T. A. Ojeyinka}

tojeyinka@oauife.edu.ng

D. O. Olayungbo

doolayungbo@oauife.edu.ng

1 Department of Economics, Obafemi Awolowo University, Ile-Ife, Nigeria 


\section{Introduction}

The crude oil prices have been experiencing large fluctuations from time to time. At the global scene, the major first global oil price shock occurred from 1973 to 1974 due to the Arabian embargo when the oil prices increased from US\$3 to US\$12. The second global oil price shock was due to the Iranian revolution when oil fields were closed down and oil prices rose from US\$12 to US\$18 per barrel between 1978 to 1979 (Kilian 2009). The third oil shock is the Iraq-Iran war from 1980 to 1990 when Kuwait was invaded by Iraq. During that period, oil prices jumped from US\$28 to US\$40 per barrel due to huge global demand. The past oil price hikes have been minor increase compared to the major oil price shocks that happened in 2008 and 2009 when the oil price fell from US\$100 to US\$47 per barrel due to the global financial crisis (Olayungbo 2019). The recent global oil price shock with an oil price below US\$30 was a result of the Corona pandemic which is currently ravaging the world. Indeed, the fluctuations in the global oil price have direct impacts on the retail petroleum product prices either in the upstream or downstream sector. The impacts have been studied to be either symmetric or asymmetric (Valadkhani et al. 2015; Rahman 2016; Apergis et al. 2018; Eleftheriou et al. 2018; Kang et al. 2018; Bragoudakis et al. 2020).

The responses of retail petroleum product prices to changes in the global oil price have long been generating controversies. The attributions are the result of the asymmetric response of retail petroleum product prices to the global oil price. The asymmetric movement is explained that when global oil price increases, retail petroleum product quickly follows, but when the global oil price falls, the price of retail petroleum product is usually sticky downwards. This is the hypothesis of rocket and feather proposed by Becon (1991). The work of Borenstein et al. (1997) confirmed empirically the quick response of positive retail petroleum product prices to positive crude oil prices than the negative changes for the USA and established inventory adjustment lags and market power as identified sources of asymmetric pricing. The debate on the asymmetric response of retail petroleum is crucial to oil-exporting countries with the resultant loss of welfare for home oil consumers when home sellers charge an excessive price above the marginal cost even after a fall in the global oil price. The asymmetric hypothesis is particularly relevant for Nigeria, as an oilexporting country, with the failure of a corresponding fall in the pump price of petrol whenever there is a fall in the global market. It is only recently that the pump price was reduced from N145 to N125 per litre by the Petroleum Product Pricing Regulatory Agency (PPPRA) as a result of the fall in the crude oil prices below US\$30 per barrel, wiping off subsidy on retail pricing product (Nigerian National Petroleum Corporation (NNPC), 2020). In many cases when the global oil price falls, Nigerians at home do not usually benefit. The experience in Nigeria is supported by Delpachitra (2002) that price changes in the home country do not usually correlate with the changes in the global oil price.

Most of the studies on the asymmetric effects of crude oil prices on retail petroleum prices were on developed countries, while limited studies are available for an emerging country like Nigeria. For instance, most recent studies such as Valadkhani 
et al. (2015) were done for the Australian gasoline market, Rahman (2016) done for the US gasoline market, Apergis et al. (2018) for 5 developed countries such as Italy, Spain, Greece, UK and the USA, Eleftheriou et al. (2018) also for US gasoline market, Kang et al. (2018) for US gasoline market, while the study of Bragoudakis et al. (2020) was done for Greek gasoline market. There is no known study for Nigeria despite the country being the largest exporter of crude oil in Africa and given the oil price shocks that have affected the country since she started exporting crude oil from the 1970s to date. Moreover, Nigeria is an oil-dependent economy with its yearly budget tied to the movement of the global crude oil price. Nigeria's budget is currently being affected by the fall in oil price due to the Coronavirus pandemic such that the budget had to be reviewed downwards from the former benchmark oil price of US\$57 to US\$28 per barrel (Central Bank Nigeria 2020). This is the first known study that examines the asymmetric effects of crude oil prices on petroleum prices in Nigeria. Furthermore, we employ the use of the hidden cointegration method proposed by Granger et al. (2002) as opposed to the standard cointegration tests such as Engle et al. (1987) and Johansen (1988). The hidden cointegration test is capable of capturing the asymmetric effects and the pass-through transmission process from crude oil prices to the retail petroleum price product. The rest of the paper is as follows. Section 2 presents the literature review. Section 3 gives the relevant theories, while Sect. 4 provides the methodology. Finally, Sect. 5 gives the empirical findings, while Sect. 6 concludes.

\section{Literature review}

\subsection{Theoretical foundation}

The phenomenon of "rocket and feather", proposed by Bacon (1991), on the response of gasoline price to crude oil price changes has continued to generate an ongoing debate among researchers and policymakers in the energy sector across the globe. The phenomenon rests on the proposition that refined petroleum product prices increase faster to an increase in crude oil prices like "rockets", while petroleum prices decrease slowly like "feather" when there is a fall in the price of crude oil. Alternatively, this relationship has been described as the "asymmetry" behaviour of petroleum price sensitivity to crude oil price changes by some authors (Borenstein et al. 1997; Liu Margaritis et al. 2010; Douglas et al. 2010; Rahman 2016). It has been observed that petroleum dealers and energy companies alter (increase) their pump prices immediately after a surge in crude oil prices. On the other hand, to maintain their margin, they are reluctant to reduce their prices when there is a slump in the oil market. In the literature, two major themes have been extensively discussed on petroleum price-crude oil price nexus, albeit with mix and inconclusive results. These are the magnitude and speed of adjustment with which petroleum price reacts to changes in crude oil prices. However, most studies in this area have focused on the USA (Borenstein et al. 1997; Bachmeier et al. 2003; Douglas et al. 2010; Rahman 2016; Sun et al. 2018; Kang et al. 2018) and European countries 
(Venditti 2010; Liu et al. 2010; Frondel et al. 2015) with limited evidence on the developing countries and particularly on the Nigerian economy.

\subsection{Empirical studies}

Starting with the pioneer study of Borenstein et al. (1997), the authors examined the response of gasoline price in the USA to changes in crude oil price adopting twostage least square on weekly data from $3 / 7 / 86$ to $11 / 20 / 92$. The authors confirmed that gasoline prices respond quickly and faster to an increase in crude oil prices than a decline in oil prices. However, the authors identified sellers' market power and disruption in supply as two major factors accounting for the asymmetric pass-through. Following the findings of Borenstein et al. (1997), a stream of studies using different methodologies have validated the conclusion that gasoline prices react asymmetrically to changes in crude oil prices. Still, on the US economy, Chen et al. (2005) employed the threshold error correction model to uncover the sensitivity of gasoline price to crude oil price shocks using weekly data from January 1991 to March 2003. The study confirmed the findings of Borenstein et al. (1997) and documented that gasoline prices respond asymmetrically to crude oil price changes. Liu et al. (2010) employed VAR and documented asymmetry link between diesel price and crude oil price in New Zealand; Rahman (2016) employed the SVAR method and obtained evidence of the asymmetric impact of crude oil prices on gasoline prices in the USA; Sun et al. (2018a, b) adopted the threshold autoregressive interval (TARI) to examine the pass-through effect of crude oil prices on gasoline prices for the USA and found that gasoline price responded asymmetrically to crude oil price for the entire sample period of 2000 to 2017. Their finding is validated by the recent studies of (Chen et al. 2021) for the Chinese economy, Choi et al. (2020) for Hong Kong and Macao cities of China. It is obvious from the studies above that empirical evidence tends to support the asymmetric response of petroleum prices to crude oil prices especially in developed countries.

Nonetheless, some researchers have argued against the asymmetric relationship between refined petroleum prices and crude oil prices, thereby challenging the "rocket and feather hypothesis" of Bacon (1991) for the UK and the seminar work of Borenstein et al. (1997) on the US economy. One of the earliest studies in this strand is Bachmeier et al. (2003) who found evidence to reject the conjecture that gasoline and crude oil prices are related in asymmetric manners in the USA. The authors decomposed both the gasoline and crude oil prices into their positive and negative components and used the standard error correction model to account for the longrun relationship among the series. Using daily data on crude oil prices and US gasoline prices between February 1985 and November 1998, the study found that gasoline prices responded instantly and symmetrically to changes in crude oil prices. The authors concluded that higher-frequency data such as daily data and different methodologies invalidate the asymmetry evidence obtained by the earlier studies. Buttressing the findings of Bachmeier et al. (2003), Venditi (2010) employed the nonlinear impulse response function to analyse the response of gasoline prices to crude prices in the USA and four major European economies involving Germany, Italy, 
France and Spain. Using weekly data between January 1999 and September 1999, the author found no evidence to support the asymmetric relationship between petroleum prices and crude oil prices both for the US and Euro area. In the same way, Liu et al. (2010) found evidence of the symmetric link between petroleum prices and crude oil prices for the New Zealand economy between 2004 and 2009. For the Irish and UK, Bermingham et al. (2011) used the Threshold Autoregressive model and found no evidence to support the "rocket and feather" hypothesis for the two economies. Hence, the authors rejected Bacon's (1991) conclusion on the response of gasoline prices to crude oil prices in the UK. Using monthly data on crude oil and US gasoline prices, Bompass et al. (2015) explored the response of gasoline to crude oil prices. Adopting the Johansen cointegration method and developing a threshold model, the authors found no evidence to support the asymmetric evidence identified by the earlier studies in the USA. The author cited an inappropriate cointegration test as a major source of asymmetric results. In the same vein, Ogbuagbor et al. (2018) reject the hypothesis of the asymmetric response of gasoline prices to international crude oil prices in South Africa. Using a single-step nonlinear autoregressive distributed lag (ARDL), Apergis et al. (2018) obtained a symmetric passthrough of crude oil prices to gasoline prices for the Greece, UK and US economies. The results contradicted the earlier finding of Atil et al. (2014) who used a similar methodology but established asymmetric relation between gasoline and natural oil prices and crude prices. However, unlike other studies that confirmed the "rocket and feather" hypothesis, Atil et al (2014) observed that the decline in gasoline prices to crude oil price reduction was larger than that of an increase in oil price.

Overall, the review above reveals that different data frequencies and methods have been employed to analyse the asymmetric effect of positive and negative oil price shocks on gasoline prices. These might have accounted for heterogeneous findings among these studies. In terms of frequency, studies such as Bachmeier et al. (2003) and Frondel et al. (2015) analysed daily data, while Bornstein et al. (1997), Chen et al. (2005), Liu et al. (2010) and Sun et al. (2018a, b) used weekly data. In addition, some authors employed monthly data to analyse the pass-through transmission of oil prices with different findings. From the methodology angle, Atil et al. (2014) and Apergis et al. (2018) adopted the nonlinear ARDL; Bachmeier et al. (2003), Frondel et al.(2015) utilized the error correction cointegration test while studies such as Kilian (2010), Ratti (2018) and Rahman (2016) adopted the VAR/SVAR techniques with varying results. One major weakness of these approaches is that they are limited to only two regimes. On the other hand, Honarvar (2009) and Karagiannis et al. (2015) employed the hidden cointegration technique to examine the cointegrating relationship and the pass-through of crude oil prices to gasoline prices. This study follows the work of Honarvar (2009) by adopting the hidden cointegration approach proposed by Granger et al. (2002) due to its advantages over other techniques. Of all these approaches, hidden cointegration stands out as the most superior technique in that it is flexible and can be applied when there are more than two regimes. Similarly, hidden cointegration helps to examine all possible combinations of cointegrations between the components of the variables involved. Lastly, as documented by Karagiannis et al. (2015) and Honarvar (2009), the method provides information on 
the pass-through transmission of crude oil prices to petroleum prices and for the testing of asymmetry/symmetry in the transmission of upstream prices.

Despite the plethora of studies on crude oil prices-petroleum/gasoline prices nexus, there seems to be a dearth of work on the subject in African countries and particularly in Nigeria. In fact, of all the studies reviewed, only Ogbuagbor et al. (2018) and Kpodar et al. (2017) considered the asymmetric response of gasoline prices to crude oil prices in South Africa and sub-Sahara Africa, respectively, while there is none on the Nigerian energy market notwithstanding the significance of oil to the Nigerian economy. Most studies in Nigeria have concentrated more on the effect of oil price shocks on macroeconomic variables such as output, inflation, stock market and exchange rate (Ayadi 2005; Babatunde 2015; Olomola et al. 2006; Riman et al. 2013; Oyelami et al. 2016; Bala et al. 2018, Oyelami 2018; Shitile et al. 2020 among others). Besides, studies that focus on the energy sector in Nigeria dwell more on the effect of economic growth and financial development on energy consumption (Rafindadi et al. 2014; Rafindadi, 2016; Rafindadi et al. 2016). Thus, to the best of our knowledge, no known study has examined the impact of upstream prices (crude oil) on the downstream prices (petroleum price) in the context of the Nigerian economy. One major input in the production process is oil and as such, any sporadic movement in oil price will have a colossal impact on the productive sector of the economy. Besides, due to the significance of the oil sector on the Nigerian economy, the prices of major consumer goods in the country are tied to movement in the petroleum price. Therefore, the way and manner the petroleum prices adjust to the swing in the oil prices will have multiple impacts on the overall performance of the economy as well as the welfare of the Nigerian citizens. Hence, there is a need to examine the transmission of crude oil prices to petroleum prices in an oil-dependent economy such as Nigeria. As argued above, the current study appears to be the pioneering work on the pass-through effects of crude oil prices on petroleum prices in Nigeria.

\section{Structure of the oil markets and the pricing behaviour}

The structure of the oil global market in the global scene consists of regional oil producers such as North America, Central America, Europe, Common Wealth of the Independent States, the Middle East, Africa and the Asia Pacific. Among the regions, Middle East is the largest world producer with a global oil contribution of $34.1 \%$, followed by North America with $21.7 \%$ and the third world largest is the Common Wealth Independent States with $15.4 \%$ of global oil production (British Petroleum Organization for Petroleum Exporting Countries (OPEC) Annual Statistical Bulletin 2019). Africa is fourth with 8.7\%, followed by the Asia Pacific with $8.5 \%$ and lastly by Europe with $3.8 \%$ of the world oil production. In most cases, the global oil price is given for African countries. This is because Africa produces just a small proportion of the global output which cannot influence the global price level. The dominant countries that dictate the global price levels are the USA with $14.1 \%$ of the global share, Russia with $12.2 \%$ and Saudi Arabia with 12.9\%. These countries can control the global oil price with their relatively high share of global oil 
production. Some oil-producing countries have merged to form cartels to influence the price. For instance, OPEC produces $42.6 \%$ of world oil production and uses the share to influence the global oil price by cutting oil supply as it deems fit. Nigeria, as a member of OPEC, is subject to the oil production quota allocated to her by OPEC.

As regards the domestic economy where the retail price of petroleum products is determined either by government regulation as the case in Nigeria or by the market situation in some countries. Many processes are involved before the product gets to the final consumer. In the case of Nigeria, there are many operating foreign and domestic oil companies with the Nigerian National Petroleum Corporation (NNPC) being the government representative in the oil industry. When the oil is drilled with Joint Venture Financing (JVF) by NNPC and its partners like ExxonMobil, Total, Chevron and the rest, the refined oil is moved to the depot, then to the marketers and through their filling stations to the end-users (final consumers). Many reasons have been identified for asymmetric pricing in the retail pricing of petroleum products. We have monopoly pricing where one single firm controls output and price. Secondly, there is the Cournot and Bertrand type pricing where there are few firms in an industry (Oligopoly) having the concentration and market power. In addition, markup pricing is the profit margin between the cost price and the market price. It has been argued that filling stations closer to oil depot may incur lower costs than farther stations and thus asymmetric pricing can result (Bacon et al. 2010). Asymmetric pricing can also happen at the upstream when some firms have access to domestic refinery, while others may have to contend with exchange volatility by refining abroad. Lastly, there are lags in price settings where monopolist waits to adjust the costly price. When cost increases, they increase the price as well, but when it is the opposite, they wait to adjust prices; a lag between an initial cost change and the resulting price change can occur (Menu cost).

\section{Data and methodology}

\subsection{Sources of data and variable description}

The data for this study were sourced from Energy Information Administration (EIA 2020) and Central bank of Nigeria (CBN) Statistical Bulletin (2020) ranging from the first quarter of 1973 to the second quarter of the year 2020 making 190 observations. The choice of the base year is because Nigeria started oil exploration in commercial quantity in the early 1970s, and the end date is informed by data availability. Specifically, there are two key variables in this study: international crude oil price and petroleum product prices. There are two benchmark oil prices globally recognized in the literature which are Brent North Sea Crude (Commonly refers to as Brent) and West Texas Intermediate (WTI). Brent crude's price is the benchmark for African, European and Middle Eastern crude oil while WTI is often used as the benchmark in North America. In this study, we use the Brent oil price as a proxy for crude oil price and the data on this variable are sourced from the EIA (2020). The Brent oil price is measured in US dollars per barrel. The Brent oil price is chosen instead of the West Texas Intermediate (WTI) oil price because Brent oil is 
ubiquitous and most oil is priced using Brent Crude as the benchmark (EIA 2020). Besides, Brent crude oil price accounts for two-thirds of oil pricing and the world's crude oil production (EIA 2020). To justify the usage of Brent oil prices, Ederington et al. (2019) argue that the model in which Brent oil is used as an independent variable tends to have more explanatory power than the equation that contains WTI. More specifically, Nigeria's crude oil export is priced and sold in the Brent oil market rather than the WTI oil price in the US oil market and hence the choice of Brent Crude oil price as the international crude oil price in the study. The second variable is the petroleum price which is obtained from the Central Bank of Nigeria Statistical Bulletin 2020 edition. The pump price is the final price the oil marketers sell to the final consumers through their filling stations. The petroleum price is expressed in Nigerian currency (Naira) per litre, while Brent price is quoted in US dollar per barrel.

\subsection{Hidden cointegration}

This study employs the Granger et al. (2002) approach to unravel the possibility of a cointegrating relationship among the subcomponents of petroleum and crude oil prices. This is necessitated by the fact that the traditional cointegration methods might fail to detect the existence of a long-run relationship between the original data. Hence, the process for hidden cointegration as proposed by Granger et al. (2002) and Honarvar (2009) is presented below.

If we assume $C P_{t}$ and $P P_{t}$ are two random walk variables defined as:

$$
\begin{aligned}
& C P_{t}=C P_{t-1}+\mu_{t}=C P_{0}+\sum_{i=1}^{t} \mu_{t} \\
& P P_{t}=P P_{t-1}+\lambda_{t}=P P_{0}+\sum_{i=1}^{t} \lambda_{i}
\end{aligned}
$$

where $t=1,2, \ldots, T$ is the time and $\lambda_{i}, \mu_{i}$ are the white noise error terms with zero mean. Also, $C P_{0}$ and $P P_{0}$ represent the initial values crude oil and petroleum price. The standard cointegration tests suggest variables $C P_{t}$ and $P P_{t}$ should co-move in the long run if they are cointegrated. However, when there is no evidence of cointegration between the two series, there might be a need to test for hidden cointegration between their positive and negative components.

Following Honarvar (2009) and Granger et al. (2002), positive and negative shocks are defined in the following ways.

$$
\begin{aligned}
& \mu_{i}^{+}=\max \left(\mu_{i}, 0\right), \mu_{i}^{-}=\min \left(\mu_{i}, 0\right) \\
& \lambda_{i}^{+}=\max \left(\lambda_{i}, 0\right), \lambda_{i}^{-}=\min \left(\lambda_{i}, 0\right)
\end{aligned}
$$


where $\left(\mu_{i}^{+}, \lambda_{i}^{+}\right)$and $\left(\mu_{i}^{-}, \lambda_{i}^{-}\right)$are positive and negative shocks, respectively. Following this, it can be concluded that the addition of both negative and positive shocks produces the total shocks as presented below.

$$
\mu_{i}=\mu_{i}^{+}+\mu_{i}^{-} \text {and } \lambda_{i}=\mu_{i}^{+}+\lambda_{i}^{-}
$$

Therefore, by decomposing $C P_{t}$ and $C P_{t}$ into positive and negative components, Eqs. (1) and (2) can be represented as

$$
\begin{gathered}
C P_{t}=C P_{t-1}+\mu_{t}=C P_{0}+\sum_{i=1}^{t} \mu_{i}^{+}+\sum_{i=1}^{t} \mu_{i}^{-} \\
P P_{t}=P P_{t-1}+\lambda_{t}=P P_{0}+\sum_{i=1}^{t} \lambda_{i}^{+}+\sum_{i=1}^{t} \lambda_{i}^{-}
\end{gathered}
$$

Hence, positive and negative shocks to each variable can be represented as.

$$
C P_{t}^{+}=\sum_{i=1}^{t} \mu_{i}^{+}, C P_{t}^{-}=\sum_{i=1}^{t} \mu_{i}^{-}, P P_{t}^{+}=\sum_{i=1}^{t} \lambda_{i}^{+}, P P_{t}^{-}=\sum_{i=1}^{t} \lambda_{i}^{-}
$$

Following the above notations, we can present Eqs. (3) and (4) in the following forms

$$
\begin{aligned}
& C P_{t}=C P_{0}+C P_{t}^{+}+C P_{t}^{-} \\
& P P_{t}=P P_{0}+P P_{t}^{+}+P P_{t}^{-}
\end{aligned}
$$

Equations (5) and (6) show that the value of a variable is the sum of the initial value plus the sum of the positive and negative components of such variable. In Eq. (5), $C P_{t}^{+}$denotes an unanticipated increase in crude oil prices, while $C P_{t}^{-}$captures the unanticipated fall in crude oil prices.

To compute the components of both series, we take the first difference of the petroleum and crude oil prices $\left(\Delta P P_{t}=P P_{t}-P P_{t-1}\right)$ and $\left(\Delta C P_{t}=C P_{t}-C P_{t-1}\right)$. Thereafter, we sort out the observations from the first difference form into positive and negative changes $\left(\Delta P P_{t}^{+}, \Delta P P_{t}^{-}, \Delta C P_{t}^{+}, \Delta C P_{t}^{-}\right)$. Lastly, we calculate the cumulative sum of positive and negative changes at a given time for all the variables $\left(C P_{t}^{+}=\sum \Delta C P_{t}^{+}, C P_{t}^{-}=\sum \Delta C P_{t}^{-}, P P_{t}^{+}=\sum \Delta P P_{t}^{+} P P_{t}^{-}=\sum \Delta P P_{t}^{-}\right)$. According to Granger et al. (2002), crude oil and petroleum prices have hidden cointegration if the components are cointegrated. Using the Engle-Granger approach, we test for the existence of cointegration among positive and negative components of the two prices.

\subsection{Symmetry and asymmetry error correction models}

The principal aim of this paper is to analyse the response of petroleum prices to changes in crude oil prices. In modelling the transmission of crude oil prices, we follow the 
studies of Bachmeier et al. (2003), Geweke (2004), Meyler (2009) and Frondel et al. (2015) by focusing only on crude price as a major determinant of petroleum prices in Nigeria. The modelling style is based on the fact that crude oil is a principal input in the production of petroleum products. Based on this argument, we formulate a simple longrun model as follows

$$
P P_{t}=\alpha_{0}+\alpha_{1} C P_{t}+\varepsilon_{t}
$$

where $P P_{t}$ and $C P P_{t}$ are petroleum and crude oil prices, respectively, $\alpha_{0}$ is the intercept, $\alpha_{1}$ is the slope that measures the long-run effect of crude oil prices on petroleum prices and $\varepsilon_{t}$ is the residual term. The first step in estimating Eq. (7) is to determine the order of integration of the variables. If the series are non-stationary (that is I (1)) and are of the same order, we test for the possibility of a cointegrating relationship between the crude oil and petroleum prices. We recover the residual of Eq. (7) and subject it to the ADF test to examine its unit root property. If the residual term is stationary based on the Engel and Granger test, it indicates a cointegrating relationship between crude oil and petroleum prices and thus specifies the symmetry or standard ECM as

$$
\Delta P P_{t}=\beta_{0}+\beta_{1} \Delta C P_{t}+\theta E C M_{t-1}+\mu_{t}
$$

Equation (8) represents the standard ECM where $\beta_{i}$ and $\eta_{j}$ are short-run coefficients, $\theta$ is the speed of adjustment parameter, $E C M_{t-1}$ is the lagged of the residual obtained from Eq. (7) and $\mu_{t}$ is the residual term.

However, if there is no cointegration between the original series, we test for hidden cointegration among the components of the two prices using the Granger et al. (2002) approach. In doing this, we consider all possible combinations of positive and negative components. For instance, if we discover a cointegrating relationship for positive components $\left(\mathrm{PP}_{t}^{+}, \mathrm{CP}_{t}^{+}\right)$, the long run between the two components will be specified as

$$
P P_{t}^{+}=\alpha_{0}+\alpha_{1} C P_{t}^{+}+\varepsilon_{t}
$$

We test the residual $\varepsilon_{t}$ obtained after estimating Eq. (9) for unit root using the ADF test. If the residual is stationary, it implies the existence of cointegration between $P P_{t}^{+}$ and $\mathrm{CP}_{t}^{+}$. as such, the asymmetric ECM between the two cointegrating components takes the form:

$$
\Delta P P_{t}^{+}=\delta_{0}+\delta_{1} \Delta C P_{t}^{+}+\lambda E C M_{t-1}+\gamma_{t}
$$

From Eq. (10), the parameter $\lambda$ captures the speed of adjustment to long-run hidden equilibrium, while the parameter $\delta_{1}$ is the short-run coefficient. 


\section{Empirical findings}

\subsection{Descriptive statistics}

Before delving into the empirical analysis on the response of petroleum prices to crude oil prices in Nigeria, it is crucial to examine the nature and characteristics of the data series employed in the study. To achieve this, we examine the descriptive characteristics of crude oil prices and petroleum prices and the results are summarized in Table 1. It can be observed from Table 1 that the average crude oil price within the study period was $\$ 38.87$, while the mean for petroleum price in Nigeria within the same period was $\mathrm{N} 37.14$. A critical examination of the two prices reveals that Brent oil reached the historical highest price in June 2008 when crude oil was sold at $\$ 132.3$ per barrel at the world oil market. In the same vein, petroleum price per litter was sold for N65 in Nigeria. However, due to the effect of the Global Financial Crisis of 2008, crude oil prices fell significantly to \$46.5 in March 2009. However, there was no response from the petroleum prices in Nigeria as the country maintained the existing price of N65 per litre. On the contrary, due to improvement in the global economic activity, crude oil prices jumped astronomically from $\$ 91.5$ in December 2010 to $\$ 125.5$ per barrel in March 2013. Correspondingly, petroleum prices in Nigeria rose dramatically from N65 per litre to N119 to reflect the speed of adjustment to the crude oil price increase. This reflects Bacon's (1991) "rocket and feather" hypothesis between crude oil prices and petroleum prices in Nigeria as petroleum price responds quickly and largely to increase than a reduction in crude oil price, thereby confirming the asymmetric relations between the two prices.

Similarly, the standard deviation, which provides information about the spread of data from their mean, shows that crude oil and petrol prices deviated markedly from their mean and this reflects the extent of volatility in the two prices. In addition, the two series are positively skewed, while their Kurtosis revolves around 3 which is ideal for the normality of the error term. Going by the probability of the Jarque-Bera statistics, it is clear from Table 1 that there is convincing evidence to reject the normality assumption in the data series. This suggests that the error term

Table 1 Descriptive statistics

\begin{tabular}{lll}
\hline & CP & PP \\
\hline Mean & 38.869 & 37.137 \\
Median & 28.590 & 11.000 \\
Maximum & 132.320 & 145.000 \\
Minimum & 1.900 & 0.060 \\
Std. Dev & 30.065 & 47.154 \\
Skewness & 1.277 & 1.129 \\
Kurtosis & 3.709 & 3.007 \\
Jarque-Bera & 55.598 & 40.384 \\
Probability & 0.000 & 0.000 \\
Observations & 190 & 190 \\
\hline
\end{tabular}

$\mathrm{PP}=$ petroleum prices, $\mathrm{CP}=$ crude oil prices 
Table 2 Unit root test result (intercept and trend)

\begin{tabular}{llllllll}
\hline Variables & \multicolumn{2}{l}{ ADF Test } & & & PP test & \\
\cline { 2 - 3 } \cline { 6 - 8 } & Level & 1st Diff & Order & & Level & 1st Diff & Order \\
\hline $\mathrm{CP}$ & -2.658 & $-11.351 * * *$ & $\mathrm{I}(1)$ & & -2.658 & $-13.513 * * *$ & $\mathrm{I}(1)$ \\
$\mathrm{PP}$ & -2.159 & $-13.853 * * *$ & $\mathrm{I}(1)$ & & -2.003 & $-14.688^{* * *}$ & $\mathrm{I}(1)$ \\
\hline
\end{tabular}

*** denotes $1 \%$ significance level

Critical value: $1 \%=-4.008,5 \%=-3.434,10 \%=-3.140$

Table 3 Zivot and Andrews unit root test with structural break

\begin{tabular}{llllll}
\hline Variables & Level & Break date & 1st Diff & Break date & order \\
\hline $\mathrm{CP}$ & -3.859 & $2005 \mathrm{q} 1$ & $-11.782 * * *$ & $2012 \mathrm{q} 2$ & $\mathrm{I}(1)$ \\
$\mathrm{PP}$ & -4.373 & $1996 \mathrm{q} 2$ & $-14.440 * * *$ & $2012 \mathrm{q} 1$ & $\mathrm{I}(1)$ \\
\hline *** denotes 1\% significance level & & &
\end{tabular}

Critical Value: $1 \%=-4.008,5 \%=-3.434,10 \%=-3.140$

is not normality distributed. This is not surprising based on the fact that crude oil prices are highly volatile.

\subsection{Unit root tests}

To confirm the suitability of the proposed methodology, it is important to examine the stationary property of the data series. To obtain a robust result, we carried out two forms of unit root tests which include the unit root without a structural break using the ADF and PP tests and the one with a structural break with Zivot and Andrews's unit root test proposed by Zivot et al. (1992) for a single break date. The results of the two tests are reported in Tables 2 and 3.

Evidence from Table 2 shows that both the crude oil prices and petroleum prices contain unit root in their level form. However, the two prices become stationary after the first difference. The result is consistent for both the ADF and PP tests. Hence, we conclude that crude oil and petroleum prices are I (1) variables. To validate our results, we carry out the unit root test in the presence of a structural break using the Zivot and Andrew test. This will help to ascertain if the variables are indeed nonstationary at the level. We select the option that incorporates both the intercept and trend with a maximum lag length of 4 . The result of the unit root test with a structural break is presented in Table 3 .

The results in Table 3 confirm the outcomes from the traditional unit root tests. This implies that crude oil and petroleum prices have unit root in their level form as revealed by the t-statistic which is less than the critical values at all the levels of significance. However, after taking the first difference of the two series, there is strong evidence to reject the null hypothesis that the series contains a unit root. Therefore, following the results of the ADF and PP tests in Table 2, the results from the Zivot and Andrews test suggest that the crude oil prices and petroleum prices are 
integrated in the first order. Looking at the results in Table 3, there was a break in the second quarter of 2012 for Brent oil, while the petroleum price has a break date of quarter one in the year 2012. This period coincided with the period when Brent oil prices rose from $\$ 107.8$ in 2011 q4 to $\$ 125.4$ per barrel in 2012q2. For petroleum prices, the break date might be due to an $83 \%$ increase in pump price experienced between the fourth quarter of 2011 and the first quarter of 2012. Overall, we conclude that both crude oil prices (Brent) and petroleum prices are stationary at first difference, thereby validating the first prerequisite for hidden cointegration analysis. This confirms the finding of existing studies that energy prices are not stationary in level (Honarvar 2009; Lahiani et al. 2017; Sun et al. 2018a, b; Choi et al. 2020). The outcomes also validate the work of Ederington et al (2019) who conclude that oil and petroleum product prices are generally non-stationary.

\subsection{Cointegration tests}

Since the two variables in the study are I (1), it is possible for the two variables to co-move in the long run. When this happens, crude oil and petroleum prices are said to be cointegrated. Hence, we examine the existence of cointegration between crude oil prices and petroleum prices by subjecting the residual term recovered from Eq. 7 to the unit root test. To confirm the reliability of our results and for robustness, we conduct both the ADF and PP tests on the residual term with the options of intercept only and intercept with the trend and the results are presented in Table 4.

The results from the tests in Table 4 indicate that the null hypothesis of no cointegration between crude oil prices and petroleum prices cannot be rejected at $5 \%$. This is because the residual term estimated from Eq. 7 is not stationary at level based on the probability values reported in Table 4 . The absence of no cointegration is confirmed by the two tests. Hence, we convincingly argue that there is no cointegrating relationship between crude oil and petroleum prices. Despite the absence of cointegration between the actual series, Granger et al. (2002) argued that unnoticed cointegration can exist if the variables are not decomposed into their positive and negative components. This is the underlining notion of hidden cointegration proposed by the authors. The idea behind the hidden cointegration is that positive and negative components of crude oil and petrol prices can commove in the long run and as such the two prices may have hidden cointegration. Therefore, following the study of Granger

Table 4 Results from Engle and Granger cointegration tests

\begin{tabular}{llllll}
\hline Variable & \multicolumn{2}{l}{ Intercept only } & & \multicolumn{2}{l}{ Intercept and trend } \\
\cline { 2 - 3 } \cline { 5 - 6 } & $\mathrm{ADF}$ & $\mathrm{PP}$ & & $\mathrm{ADF}$ & $\mathrm{PP}$ \\
\hline Residual & $-1.442(0.561)$ & $-1.321(0.620)$ & & $-2.443(0.3570)$ & $-2.385(0.386)$ \\
& Critical values & & & $\begin{array}{l}\text { Critical values } \\
\end{array}$ \\
& $1 \%=-3.465,5 \%=-2.877,10 \%=-2.575$ & & $1 \%=-4.007,5 \%=-3.434$, \\
& & & $10 \%=-3.141$ & \\
\hline
\end{tabular}

Values in parenthesis denote the probability values 
et al. (2002) and Honarvar (2009), we separate crude oil and petrol prices into their positive and negative components. However, before we conduct the possibility of hidden cointegration among the subcomponents of the two series, there is a need to test for the unit root property of the positive and negative components of crude oil and petroleum prices to be sure the variables are non-stationary at level. The results of the unit root tests on the four subcomponents are presented in Table 5.

Again, it is evident from Table 5 that all the components have unit roots and hence are non-stationary at level. However, when the decomposed negative and positive components are taking to their first difference form, the null hypothesis of unit root is rejected for all the variables at $1 \%$. Hence, like the original data, both positive and negative components of crude oil and petroleum prices are I (1) variables and this further supports the applicability of hidden cointegration. We then test for the existence of a cointegrating relationship among the positive and negative components of both the crude price and petroleum prices.

In the literature, there are two major ways of detecting hidden cointegration among the positive and negative components of the examined variables. When the Johansen cointegration test is employed, the resulting cointegration is known as the Hatemi-J et al. (2012) hidden cointegration approach while the type of cointegration based on Engle and Granger method is defined as the Granger et al. (2002) hidden cointegration approach (Mert et al. 2020 and Boga 2020). Based on the assumption of exogeneity, we assume that petroleum prices depend on crude oil prices and not vice versa and thus we take the crude oil prices as exogenous. Hence, we develop a single equation to examine the asymmetric response of petroleum prices to crude oil prices using the Granger et al. (2002) hidden cointegration approach based on the Engle and Granger cointegration method. Following this argument, the study adopts the Engle et al. (1987) two-step approach to detect the possibility of a cointegrating relationship between positive and negative components of crude oil petroleum prices. In doing this, we estimate Eq. 9 using the OLS method and subject the residual term recovered to the unit root test to confirm whether the residual terms are stationary. The reports of the Engle-Granger cointegration test are presented in Table 6.

As presented in Table 6, there is evidence of hidden cointegration among the components of the two data series. Specifically, under the specification of the unit

Table 5 Unit root test results for the components (intercept and trend)

\begin{tabular}{llllllll}
\hline Variables & \multicolumn{1}{l}{ ADF test } & & & PP test \\
\cline { 2 - 3 } \cline { 6 - 8 } & Level & 1st Diff & Order & & Level & 1st Diff & Order \\
\hline $\mathrm{CP}^{+}$ & -0.331 & $-13.373 * * *$ & $\mathrm{I}(1)$ & & -0.483 & $-13.601 * * *$ & $\mathrm{I}(1)$ \\
$\mathrm{CP}-$ & -0.302 & $-11.266^{* * *}$ & $\mathrm{I}(1)$ & & -0.013 & $-11.062 * * *$ & $\mathrm{I}(1)$ \\
$\mathrm{PP}^{+}$ & -1.403 & $-14.290^{*} * *$ & $\mathrm{I}(1)$ & & -1.315 & $-14.393 * * *$ & $\mathrm{I}(1)$ \\
$\mathrm{PP}^{-}$ & -0.553 & $-14.154 * * *$ & $\mathrm{I}(1)$ & & -0.358 & $-14.178^{*} * *$ & $\mathrm{I}(1)$ \\
\hline
\end{tabular}

$* * *, * * *$ denote $1 \%, 5 \%$ and $10 \%$ level, respectively

Critical Values: $1 \%=-4.008,5 \%=-3.434,10 \%=-3.141$ 
Table 6 Asymmetric Engle-Granger cointegration tests

\begin{tabular}{|c|c|c|c|c|c|}
\hline \multicolumn{2}{|l|}{ Variables } & \multicolumn{2}{|l|}{ With intercept } & \multicolumn{2}{|c|}{ With intercept and trend } \\
\hline Dependent & Independent & $\mathrm{ADF}$ & PP & $\mathrm{ADF}$ & PP \\
\hline PP- & $\mathrm{CP}-$ & $-3.111(0.027)^{* *}$ & $-3.280(0.017)^{* *}$ & $-3.001(0.135)$ & $-3.002(0.135)$ \\
\hline PP- & $\mathrm{CP}+$ & $-2.243(0.192)$ & $-2.244(0.192)$ & $-2.111(0.536)$ & $-2.170(0.503)$ \\
\hline $\mathrm{PP}+$ & $\mathrm{CP}-$ & $-3.417(0.012)^{* *}$ & $-3.549(0.008)^{* * *}$ & $-3.406(0.054)^{*}$ & $-3.540(0.038)^{* *}$ \\
\hline $\mathrm{PP}+$ & $\mathrm{CP}+$ & $-2.985(0.038) * *$ & $-3.062(0.031) * *$ & $-2.959(0.147)$ & $-3.033(0.126)$ \\
\hline
\end{tabular}

i) $* * *, * * *$ denote $1 \%, 5 \%, 10 \%$ level of significance, respectively

ii) Values in parenthesis indicate the probability values

iii) PP represents Phillips-Perron test

root test with intercept only, there is strong evidence to reject the null hypothesis of no cointegration between negative (positive) components of petroleum prices and negative (positive) components of crude oil prices; and positive components of petroleum and crude oil prices and positive petroleum prices and negative crude oil prices at 5\% significance level. Both tests confirm that the identified components have a long-run relationship. This suggests that both prices have common negative and positive shocks in the long run (Granger et al. 2002) and as such, they increase and decrease together in the long run (Honarvar 2009). However, the results in Table 6 suggest no evidence of cointegration between positive changes in crude oil prices and negative changes in petroleum prices. Hence, we confirm the evidence of cointegration among the components of petroleum and crude oil prices and this supports the findings of Granger et al. (2002), Bremmer et al. (2016), Mert et al. (2020) and Boga (2020) that subcomponents of economic variables might exhibit some form of hidden cointegration even in the absence of explicit cointegration between the original variables. The long-run and short-run relationships between the cointegrated components can be represented in the following equations

$$
\begin{gathered}
P P_{t}^{-}=\rho_{0}+\rho_{1} C P_{t}^{-}+\varepsilon_{t} \\
\Delta P P_{t}^{-}=\gamma_{0}+\gamma_{1} \Delta C P_{t}^{-}+\lambda E C M_{t-1}+\lambda_{t} \\
P P_{t}^{+}=\beta_{0}+\beta_{1} C P_{t}^{-}+\mu_{t} \\
\Delta P P_{t}^{+}=\theta_{0}+\theta_{1} \Delta C P_{t}^{-}+\phi E C M_{t-1}+\eta_{t} \\
P P_{t}^{+}=\rho_{0}+\rho_{1} C P_{t}^{+}+\varepsilon_{t} \\
\Delta P P_{t}^{+}=\varphi_{0}+\varphi_{1} \Delta C P_{t}^{+}+\gamma E C M_{t-1}+\mu_{t}
\end{gathered}
$$


Table 7 Long-run model

\begin{tabular}{lllll}
\hline Dependent & Intercept & $C P^{-}$ & $C P^{+}$ & $\mathrm{R}^{2}$ \\
\hline$P P^{-}$ & $2.147^{* * *}$ & $0.104^{* * *}$ & - & $91 \%$ \\
& $(0.000)$ & $(0.000)$ & - & \\
$P P^{+}$ & $-6.793 * *$ & $-0.489 * * *$ & - & $95 \%$ \\
& $(0.000)$ & $(0.000)$ & - & \\
$P P^{+}$ & $-13.988^{* * *}$ & - & $0.414 * * *$ & $94 \%$ \\
& $(0.000)$ & - & $(0.000)$ & \\
\hline
\end{tabular}

i) $* * *, * * *$ denote $1 \%, 5 \%, 10 \%$ level of significance, respectively

ii) Values in parenthesis indicate the probability values

Table 8 Asymmetric error correction model

\begin{tabular}{lllll}
\hline Dependent & Intercept & $E C M_{t-1}$ & $\Delta C P^{-}$ & $\Delta C P^{+}$ \\
\hline$\Delta P P^{-}$ & -0.124 & $-0.124 * * *$ & $0.073 * * *$ & - \\
& $(0.447)$ & $(0.003)$ & $(0.002)$ & - \\
$\Delta P P^{+}$ & $1.005 * *$ & $-0.090^{* *}$ & 0.018 & - \\
& $(0.018)$ & $(0.003)$ & $(0.765)$ & - \\
$\Delta P P^{+}$ & $0.493 * *$ & $-0.089 * * *$ & - & $0.192 * *$ \\
& $(0.026)$ & $(0.003)$ & - & $(0.021)$ \\
\hline
\end{tabular}

i) $* * *, * * *$ denote $1 \%, 5 \%, 10 \%$ level of significance, respectively

ii) Values in parenthesis indicate the probability values

\subsection{Asymmetric response of Petroleum prices to Crude oil Price changes in Nigeria}

This study is based on the assumption of strict exogeneity in that we do not expect petroleum prices to have any impact on crude oil prices. This is because the prices of crude oil are determined at the world oil market and as such is exogenous to the Nigerian economy. A similar assumption is observed by Asche et al. (2003) and Westgaard et al. (2011) that petroleum product prices depend on crude oil prices and not vice versa. The assumption is also buttressed by the study of Meyler (2009) who observe a unidirectional causality from crude oil prices to petroleum price. In addition, Liu et al. (2010) find evidence of block exogeneity between crude oil prices and petroleum prices for New Zealand. Besides, Nigeria supplies only $2 \%$ of the global oil supply and as such, the country is a price taker in the determination of crude oil. Based on the assumption of strict exogeneity, we estimate the longrun and short-run relationships between the cointegrated components $\left[C P^{-}, P P^{-}\right.$, $\left[C P^{+}, P P^{+}\right]$and $\left[C P^{-}, P P^{+}\right]$as presented in Eqs. $11,12,13,14,15$ and 16. Tables 7 and 8 contain the results from the long run and asymmetric error correction models between petroleum price and crude oil prices.

Starting with the results of the long-run model, the outcomes from Table 7 show evidence of long-run asymmetry in the transmission of crude oil prices to petroleum prices in Nigeria. Outcomes from Table 7 suggest that the impact of negative and 
positive movements in crude oil prices significantly affects the petroleum price in Nigeria. This suggests that crude oil prices (both negative and positive) are major drivers of petroleum prices in Nigeria. Specifically, from $\left(C P^{-}, P P^{-}\right)$nexus, it can be observed from Table 7 that a negative shock to crude oil prices will reduce the petroleum price by 0.10 unit in Nigeria. Similarly, there is a direct relationship between a positive shock to crude oil prices and a positive movement in petroleum prices in Nigeria. The magnitude of $C P^{+}$, in the $\left(C P^{+}, P P^{+}\right)$relation, reveals that if there is a unit positive shock to the crude oil price, petroleum prices will rise by 0.41 unit in Nigeria compared with a reduction of 0.10 units in the case of a decrease in crude oil prices. This suggests that a one-dollar increase in crude oil price $\left(C P^{+}\right)$is larger (0.41) than a dollar decrease in the crude oil price $\left(C P^{-}\right)$which is 0.1 indicating that the impact of an increase in crude oil prices is larger and stronger than the effect of a decrease in crude oil prices on petroleum prices in Nigeria. The result confirms a significant long-run asymmetry in the response of petroleum prices to crude oil prices in Nigeria. In other words, the outcome from long-run analysis validates the rocket and feather hypothesis proposed by Bacon (1991). The findings also conform to the preponderance of evidence in crude oil-petroleum prices literature such as Chen et al (2005) and Honarvar (2009) for the USA; Chen et al. (2021) for China. This finding on asymmetric response to crude oil prices also affirms the conclusion of Ogbuabor (2018) for the European countries. In addition, Kpodar et al. (2017) also find a persistent asymmetric effect of crude oil prices on petroleum prices for Sub-Saharan Africa. However, the results contradict the outcomes of Ogbuabor (2018) for South Africa, while there is a symmetrical relationship between crude oil prices and gasoline prices. One possible reason for the disagreement in findings may be because South Africa is majorly an oil-importer, unlike Nigeria which is seeing as both the importer of petroleum and exporter of crude oil. The asymmetric link for $\left(C P^{-}, P P^{+}\right)$can also be observed in Table 7 which corroborates the significant effect of crude oil prices on petroleum prices in Nigeria. Another key message from Table 7 is the explanatory power of crude oil prices on petroleum prices. The $\mathrm{R}^{2}$ for the three models is more than $90 \%$ and this implies that crude oil price is a key determinant of petroleum price in Nigeria. This again validates the argument that crude oil prices are major drivers of petroleum prices in Nigeria.

Table 8 contains the results of the error correction model for each of the identified cointegrating components of crude oil and petroleum prices. Firstly, for a long-run relationship to exist between two variables, the coefficient of the lagged error correction term must be negative and secondly, the error term must be significant. Evidence from Table 8 suggests that the error correction terms carry appropriate signs and are statistically significant for the three models. This reiterates the cointegrating relationship between the positive and negative components of crude oil and petroleum prices. Alternatively, the magnitude of the error correction terms implies that both positive and negative changes in crude oil prices are transmitted to petroleum prices in the long run which in turn corroborates the outcome of Karagiannis et al. (2015) for the retail fuel markets in France. Germany, Italy and Spain. This again validates the results of our Engle and Granger tests presented in Table 6 that there is an asymmetric long-run relationship between crude oil and petroleum prices. The intuition behind the estimates is that crude oil price changes are responsible for 
the long-run dynamic between the two prices (Alom 2014). For instance, it can be deduced from Table 8 that negative changes in crude oil prices are responsible for a decrease in petroleum prices, while positive movement in crude oil prices accounts for an increase in the price of crude in Nigeria. The results are not surprising based on the fact that the determination of crude oil prices is completely outside the influence of oil regulators in Nigeria. Besides, movement in crude oil prices is expected to affect the petroleum prices of an oil-dependent economy.

We further analyse the nature of short-run behaviour among the cointegrating positive and negative components of the two prices. The results from the short-run model in Table 8 are similar to those obtain from the long-run model except for $\left(C P^{-}, P P^{+}\right)$combination where the coefficient of changes in a negative shock to crude oil price on positive movement in petroleum prices is not significant. However, the results from $\left(C P^{+}, P P^{+}\right)$and $\left(C P^{-}, P P^{-}\right)$relations validate the significant impact of crude oil prices on petroleum prices in the short run. In statistical terms, the effects of negative and positive shocks to crude oil prices are positive and significant on negative and positive changes in petroleum prices, respectively. By implication, petroleum prices in Nigeria are highly sensitive to movement in international oil price and this will have consequences on major macroeconomic variables in Nigeria. To uncover the short-run asymmetry in the response of petroleum prices to crude oil prices, the results in Table 8 show that the impact of positive movement in crude oil prices is larger than the effect of negative changes in crude oil. Specifically, one unit negative shocks to crude oil price will reduce petroleum prices in Nigeria by approximately 0.07 unit, while a similar increase in crude oil price will increase petroleum price by 0.19 unit indicating strong evidence of short-run asymmetry in Nigeria. The outcomes further confirm the hypothesis of "rocket and feather" in Nigeria. The result aligns with the finding of Honavar (2009), Rahman (2016) and Sun et al. (2018a, b) for the USA and Liu et al. (2010) for New Zealand. All these studies find that the gasoline price responds asymmetrically to changes in crude oil prices in the short run.

In addition, the results from Table 8 suggest that the speed of adjustment for the three cointegrating series is generally low. This implies that it takes a longer time for any disequilibrium in the system to adjust to long-run equilibrium. On the speed of adjustment of the asymmetric components between positive petroleum prices and negative crude prices, the speed of adjustment is at $9 \%$. This is reasonable and could be interpreted to mean an increase in petroleum prices does not respond quickly or faster to a decrease in the global crude oil.

Overall, the study confirms both short-run and long-run asymmetry in the transmission of crude oil prices to petroleum prices in Nigeria. A plausible reason for such behaviour is the non-competitiveness in the energy market in Nigeria. As noted in Sect. 3 of this study, energy markets in Nigeria can be categorized as an oligopolistic market where the few marketers colluded to exercise significant control over the petroleum product prices. Thus, when crude oil prices increase in the world oil market, the marketers are quick to pass the increase to the final consumers to retain their profit margin. However, when there is a downward adjustment in the crude oil price, players in the energy market are slow in adjusting their fuel pump price to prevent price war and maintain higher profit. The findings also align with the argument 
of Borenstein et al. (1994) who attributed the observed asymmetry in oil prices-gasoline prices nexus in the UK to the imperfect competition among retailers. The findings imply that the impact of an increase in crude oil prices has welfare reducing effects on the Nigerian economy indicating a welfare loss to Nigerians in terms of paying higher prices for petroleum consumption than their foreign counterparts abroad. On the other hand, Nigerian does not benefit from the reduction in crude oil prices due to the ineptitude of the retailers to correspondingly adjust the petroleum prices when there is a downward adjustment in the crude oil prices in the oil market.

\section{Conclusions}

The study investigates the asymmetric response of petroleum prices in Nigeria to changes in crude oil prices using the Engle and Granger error correction model. We apply the Granger et al. (2002) hidden cointegration to uncover the possibility of unnoticed cointegration between the decomposed positive and negative components of the two prices. The results from the hidden cointegration test confirm the evidence of the cointegrating relationship between positive and negative components of petroleum and crude oil prices and between positive components of petroleum price and negative components of crude oil prices. The results suggest that the two prices respond to common stochastic shocks and they both adjust together in the long run.

Having identified cointegration among the components of the two series, we proceed to analyse the short-run and long-run asymmetric responses of petroleum prices to crude oil prices. The results from the long-run model suggest that positive and negative changes in crude oil prices significantly affect movement in petroleum prices in Nigeria. This implies that crude oil prices play a prominent role in the determination of petroleum prices in Nigeria. In addition, evidence from the long-run behaviour reveals that the impact of positive changes in crude oil prices is larger and stronger than the effect of negative changes in crude oil prices indicating evidence of an asymmetric relationship between crude oil and petroleum prices in Nigeria. Similarly, the results of the short-run model behave in the same way as that of the long-run results. The magnitude of the error correction term is negative and significant for the three identified cointegrating components. This further attests to the fact that a long-run relationship exists between positive and negative components of the two price series. Overall, the study finds convincing evidence to support the hypothesis of "rocket and feather" in the pass-through effect of crude oil prices on petroleum prices in Nigeria. Hence, we conclude that crude oil prices are a significant driver of petroleum prices both in the short run and long run in Nigeria.

The findings of the study have some policy implications for the Nigerian economy being an exporter of crude oil and importer of refined petroleum products. The pump price of petroleum in Nigeria is strongly tied to changes in crude oil prices in the world oil market. Hence, any unexpected rise in crude prices will translate into higher petroleum prices in Nigeria. This, therefore, implies that the Nigerian economy is highly susceptible to movement in oil prices. Lastly, the rocket and feather hypothesis is established in the country and this implies that while petroleum price responds to an increase in the crude oil price, it does not similarly respond to a price 
decrease. Another implication of this to the domestic consumers in the oil-exporting country is that they are made to pay more than their foreign counterparts. This implies a welfare loss for home consumers. The policy recommendation is that the government can subsidize to reduce the cost effect on the citizens. In addition, the government can interfere by setting the appropriate price that matches the changes in the price of the global crude oil to petroleum prices. There is a need for more government intervention to reduce the adverse effect of positive oil price shocks on consumer welfare.

The study discovers that an asymmetric relationship exists between petroleum prices and crude oil prices in Nigeria. One major limitation of the present study is the lack of existing studies in crude oil-petroleum prices nexus in Nigeria to compare the findings from the study. However, the outcomes from the study agree with the findings for other countries where the asymmetric response of petroleum prices to crude oil prices has been examined especially, those countries that share similar economic characteristics with Nigeria. Also, the study does not identify the sources of the asymmetry in the nexus between oil prices and petroleum prices. Thus, there is a need to identify the sources of the asymmetry in Nigeria. This can serve as a direction for future studies on the nexus between oil prices and petroleum prices in Nigeria. Similarly, the study employs monthly data to investigate the response of petroleum prices to crude oil prices in Nigeria. However, empirical studies have shown that the frequency of data employed might affect the nature of asymmetry in the pass-through of crude oil prices to petroleum product prices. Thus, as data become available, future studies may consider the use of high-frequency data such as weekly and daily to re-assess the response of petroleum prices to crude oil prices in Nigeria or a panel study, especially among the oil-exporting countries.

\section{References}

Asche F, Gjølberg O, Veolker T (2003) Price relationships in the petroleum market: An analysis of crude oil and refined product prices. Energy Economics 25(3):289-301

Alom F (2014) An investigation into the crude oil price pass-through to the macroeconomic activities of Malaysia. Energy Procedia 79:542-548

Atil A, Lahiani A, Nguyen DK (2014) Asymmetric and nonlinear pass-through of crude oil prices to gasoline and natural gas prices. Energy Policy 65:567-573

Apergis N, Vouzavalis G (2018) Asymmetric pass through of oil prices to gasoline prices: Evidence from a new country sample. Energy Policy 114:519-528

Ayadi OF (2005) Oil price fluctuations and the Nigerian economy. OPEC Rev 29(3):199-217

Bala U, Chin L (2018) Asymmetric Impacts of Oil Price on Inflation: An Empirical Study of African OPEC Member Countries. Energies 11:1-21

Bachmeier LJ, Griffin JM (2003) New evidence on asymmetric gasoline price responses. Rev Econ Stat 85:772-776

Bacon RW (1991) Rockets and feathers: the asymmetric speed of adjustment of U.K. Retail Gasoline Prices to Cost Changes, Energy Economics 13:211-218

Bacon R, Kojima M (2010) Asymmetric petroleum product pricing in developing countries. World Bank and International Finance Corporation. www.worldbank.org/ogmc www.ifc.org/ogmc.

Babatunde MA (2015) Oil Price Shocks and Exchange Rate in Nigeria. Int J Energy Sect Manage $9(1): 1-16$

Bermingham C, O'Brien D (2011) Testing for asymmetric pricing behavior in Irish and UK petrol and diesel markets. Energy J 32(3):1-27 
Boga S (2020) Investigating the asymmetry between economic growth and unemployment in Turkey: A hidden cointegration approach. Journal of Economics, Finance and Accounting 7(1):22-33

Borenstein S, Cameron AC, Gilbert R (1997) Do gasoline prices respond asymmetrically to crude oil price changes? Quart J Econ 112:305-339

Borenstein S, Shepard A (1994) Dynamic pricing in retail gasoline markets. Rand Journal of Economics 27(3):429-451

Bragoudakis Z, Degiannakis S, Filis G (2020) Oil and pump prices; testing their asymmetric relationship in a robust way. Energy Economics 88:1-12.

Bremmer DS, Kesselring RG (2016) The relationship between U.S. Retail gasoline and crude oil prices during the great recession: "rockets and feathers" or "balloons and rocks" behavior?, Energy Economics doi:https://doi.org/10.1016/j.eneco.2015.12.014

Bumpass D, Ginn V, Tuttle MH (2015) Retail and wholesale gasoline price adjustments in response to oil price changes. Energy Economics 52:49-54

British Petroleum OPEC Annual Statistical Bulletin, 2019. www.opec.org/opec-web Accessed 12th June, 2020.

Central Bank of Nigeria, Statistical Bulletin, 2020. Abuja, Nigeria. www.cbn.gov.ng Accessed $20^{\text {th }}$ June, 2020.

Chen LH, Finney M, Lai KS (2005) A threshold cointegration analysis of Asymmetric price transmission from crude oil to gasoline prices. Econ Lett 89:233-239

Chen H, \& Sun Z (2021) International crude oil price, regulation and asymmetric response of China's gasoline price. Energy Economics, 94, 105049.

Choi K, Liu MH, \& Zhang Y (2020) The relationship between refined retail oil prices and crude oil prices: a tale of three cities in the greater bay area of China. The Chinese Economy, 1-19.

Delpachitra SB (2002) Price rigidity in the downstream petroleum industry in New Zealand: where does it happen? Energy Economics 24:597-613

Douglas C, Herrera AH (2010) Why are gasoline prices sticky? A test of alternative models of price adjustment. J Appl Economet 25:903-928

Ederington LH, Fernando CS, Hoelscher SA, Lee TK, Linn SC (2019) A review of the evidence on the relation between crude oil prices and petroleum product prices. J Commod Mark 13:1-15

Eleftheriou K, Nijkamp P, Polemis ML (2018) Asymmetric price adjustments in US gasoline markets: impacts of spatial dependence on the 'rockets and feathers' hypothesis.Reg. Stud. 1-14.

Energy Information Administration, United State, www.eia.gov. Accessed 20th June, 2020.

Energy Information Administration (2020). Drop in U.S. Gasoline Prices Reflects Decline in Crude Oil Costs. https://www.eia.gov/todayinenergy/detail.php? Id=6850. Accessed Nov. 2, 2020.

Engle RE, Granger CWJ (1987) Cointegration and error correction: Representation, estimation and testing. Econometrica 55:251-276

Frondel F, Vance C, Kihn A (2015).Time Lags in the Pass-Through of Crude- Oil Prices - Big Data Evidence from the German Gasoline Market. Ruhr Economic Papers \#573.

Granger CW, Yoon G (2002) Hidden cointegration. Department of Economics Working Paper. University of California, San Diego.

Geweke, J., (2004). Issues in the Rockets and Feathers gasoline price literature. Report to the Federal Trade Commission.

Hatemi-J A (2012) Asymmetric causality tests with an application. Empir Econ 43(1):447-456

Honarvar A (2009) Asymmetry in retail gasoline and crude oil price movements in the United States: an application of hidden cointegration technique. Energy Econ 31:395-402

Johansen S (1988) Statistical analysis of cointegration vectors. J Econ Dyn Control 12:231-254

Kang W, Gracia FP, Ratti RA (2018) The asymmetric response of gasoline prices to oil price shocks and policy uncertainty. Energy Economics. https://doi.org/10.1016/j.eneco.2018.09.007

Karagiannis S, Panagopoulos Y, Vlamis P (2015) Are unleaded gasoline and diesel price adjustments symmetric? A comparison of the four largest EU retail fuel markets. Economic Modelling 48(C): $281-291$

Kilian L (2009) Not All Oil Shocks Are Alike: Disentangling Demand and Supply Shocks in the Crude Oil Market. American Economic Review 1053-1069.

Kilian L (2010) Explaining fluctuations in gasoline prices: a joint model of the global crude oil market and the US retail gasoline market. Energy J 31(2):87-112

Kpodar K, Abdallah C (2017) Dynamic fuel price pass-through: Evidence from a new global retail fuel price database. Energy Economics 66:303-312 
Liu MH, Margaritis D, Tourani-Rad A (2010) Is there an asymmetry in the response of diesel and petrol prices to crude oil price changes? Evidence from New Zealand. Energy Economics 32:926-932

Lahiani A, Miloudi A, Benkraiem R, Shahbaz M (2017) Another look on the relationships between oil prices and energy prices. Energy Policy 102:318-331

Mert M, Caglar AE (2020) Testing pollution haven and pollution halo hypotheses for Turkey: a new perspective. Environ Sci Pollut Res. https://doi.org/10.1007/s11356-020-09469-7

Meyler A (2009) The pass through of oil prices into euro area consumer liquid fuel prices in an environment of high and volatile oil prices. Energy Economics 31(6):867-881

Nigerian National Petroleum Corporation. (NNPC), 2020. Corporate Headquarters NNPC Towers, Central Business District, Herbert Macaulay Way, P.M.B. 190, Garki, Abuja, Nigeria www.nnpcgroup. com. Accessed $18^{\text {th }}$ June 2020.

Ogbuabor JE, Eigbiremolen GSO, Manasseh CO, Mba IC (2018) Asymmetric price transmission and rent-seeking in road fuel markets: A comparative study of South Africa and selected Eurozone countries. Afr Dev Rev 30(3):278-290

Olayungbo DO (2019) Asymmetric effects of oil revenue shocks on government spending composition and productive sectors: new evidence from Nigeria. OPEC Energy Review Wiley.1-18

Olomola PA, Adejumo AV (2006) Oil Price Shocksand Macroeconomic Activities in Nigeria. Int Res J Financ Econ 3:28-34

Oyelami LO, Olomola PA (2016) External Shocks and Macroeconomic responses in Nigeria: a Global VAR approach. Cogent Economics and Finance 4:1239317

Oyelami LO (2018) Effects of oil price movement on Nigerian macroeconomic variables: evidence from linear near and nonlinear ARDL modelling. Iran Econ Rev 22(4):908-933

Rafindadi AA, Yusof Z (2014) Do the Dynamics of Financial Development spur Economic Growth in Nigeria's contemporal economic growth struggle? A fact beyond the figures. Proceeding - Kuala Lumpur International Business, Economics and Law Conference 2:136-157

Rafindadi AA (2016) Does the need for economic growth influence energy consumption and CO2 emissions in Nigeria? Evidence from the innovation accounting test. Renew Sustain Energy Rev 62:1209-1225

Rafindadi AA, Mika'Ilu AS (2019) Sustainable energy consumption and capital formation: Empirical evidence from the developed financial market of the United Kingdom. Sustainable Energy Technol Assess 35:265-277

Rahman S (2016) Another Perspective on Gasoline Price Responses to Crude Oil Price Changes. Energy Economics. https://doi.org/10.1016/j.eneco.2015.12.021

Riman HB, Akpan ES, Offiong AI (2013) Asymetric Effect of Oil Price Shocks on Exchange Rate Volatility and Domestic Investment in Nigeria. MPRA Paper No. 53282.

Shitile TS, Usman N (2020) Disaggregated Inflation and Asymmetric Oil Price Pass-Through in Nigeria. International Journal of Energy Economics and Policy 10(1):255-264

Sun Y, Han A, Hong Y, Wang S (2018a) Threshold autoregressive models for Interval-valued time series. Journal of Econometrics 206:414-446

Sun Y, Zhang X, Hong Y (2018b) Wang S (2019) Asymmetric pass-through of oil prices to gasoline prices with interval time series modelling. Eneeco. https://doi.org/10.1016/j.eneco.2018.10.027

Valadkhani A, Smyth R, Vahid F (2015) Asymmetric pricing of diesel at its source. Energy Econ 52:183-194

Venditti F (2010) Down the Non-Linear Road from Oil to Consumer Energy Prices: Not Much Asymmetry along the Way. Bank of Italy Working Paper no. 751.

Westgaard S, Estenstad M, Seim M, Frydenberg S (2011) Co-integration of ICE gas oil and crude oil futures. Energy Economics 33(2):311-320

Zivot E, Andrews DWK (1992) Further evidence on the great crash, the oil-price shock and the unit root hypothesis. J Bus Econ Stat 10(3):251-270

Publisher's Note Springer Nature remains neutral with regard to jurisdictional claims in published maps and institutional affiliations. 